\title{
EFFECT OF THE SKIN-CORE MORPHOLOGY ON THE MECHANICAL PROPERTIES OF INJECTION-MOULDED PARTS
}

\author{
VPLIV MORFOLOGIJE SKORJA-JEDRO NA MEHANSKE \\ LASTNOSTI VBRIZGANIH DELOV
}

\author{
Eva Hnatkova ${ }^{1,2}$, Zdenek Dvorak ${ }^{1,2}$ \\ ${ }^{1}$ Department of Production Engineering, Faculty of Technology, Tomas Bata University in Zlín, Vavreckova 275,76001 Zlín, Czech Republic \\ ${ }^{2}$ Centre of Polymer Systems, University Institute, Tomas Bata University in Zlín, Trida T. Bati 5678, 760 01 Zlín, Czech Republic \\ ehnatkova@ft.utb.cz \\ Prejem rokopisa - received: 2014-07-31; sprejem za objavo - accepted for publication: 2015-04-13
}

doi:10.17222/mit.2014.151

\begin{abstract}
The presented study deals with the effects of different processing parameters during injection moulding on the morphological structure through the thickness of the injection-moulded samples and, consequently, on their mechanical properties. In this work, tensile bars of an isotactic polypropylene were injected under different conditions such as the flow rate, the melt temperature and the mould temperature. The morphological structure of the samples was investigated with polarized light microscopy using thin cross-sections cut perpendicularly to the flow direction. The fountain flow in the mould cavity influenced the crystallization kinetics and the presence of three distinct crystalline zones was observed; namely, the highly oriented non-spherulitic skin, the shear-nucleated spherulitic intermediate layer and the inner core composed of spherulites with a low orientation. The results showed that the flow rate has the highest influence on the thickness of the oriented skin layer. The mechanical properties of the tensile samples demonstrated that the larger thickness of the two outer skins provides the higher tensile strength. The same effect was also confirmed with a microhardness test where the skin layer was harder than the inner spherulitic core.
\end{abstract}

Keywords: skin-core structure, polypropylene, morphology, tensile strength, microhardness

Predstavljena študija obravnava vpliv različnih procesnih parametrov pri vbrizgavanju na morfologijo strukture, zaradi debeline vbrizganih vzorcev, in posledično na njihove mehanske lastnosti. V tem delu so bile natezne palice izotaktičnega propilena vbrizgane pri različnih pogojih, kot so: hitrost tečenja, temperatura snovi in temperatura kokile. Morfološka struktura vzorcev je bila preiskovana $\mathrm{z}$ mikroskopijo s polarizirano svetlobo, z uporabo tankih rezin, odrezanih pravokotno na smer toka. Lijakasto litje v votlini orodja je vplivalo na kinetiko kristalizacije in opažena je bila prisotnost treh različnih kristalnih področij, in sicer: močno orientirana ne-sferulitna skorja, s striženjem nukleirana sferulitna vmesna plast in notranje jedro, sestavljeno iz sferulitov, brez orientacije. Rezultati so pokazali, da ima hitrost toka največji vpliv na debelino skorje. Mehanske lastnosti nateznih preizkušancev so pokazale, da večja debelina dveh zunanjih skorij zagotavlja višjo natezno trdnost. Enak učinek je bil potrjen tudi s preizkusom mikrotrdote, kjer je bila plast skorje bolj trda kot pri notranjem sferulitnem jedru.

Ključne besede: struktura skorja-jedro, polipropilen, morfologija, natezna trdnost, mikrotrdota

\section{INTRODUCTION}

It is well known that the internal morphological structure of a semi-crystalline polymer is strongly dependent on the processing parameters during the injection moulding. ${ }^{1-3}$

The injection of a molten polymer into a relatively cold mould immediately leads to a frozen layer of the polymer at the cavity wall. Then, the melt flow inside takes place between two frozen layers. This mechanism is called the fountain flow. The molecules at the flow front are elongated before their deposition on the cold cavity and, because of the rapid solidification, the surface layer shows a high degree of molecular orientation. In the centre of the flow, the material has more time to relax and crystallize, although even here the shear flow also generates orientation. ${ }^{4}$ The internal morphology displays a strong structural heterogeneity through the cross-section of a sample thickness. This structural deve- lopment consequently affects the mechanical properties of the final components. ${ }^{5}$

Many studies about injection-moulded polypropylene (PP) have shown that at least two regions are noticeable through a specimen thickness. ${ }^{6,7}$ The first frozen surface layer is called "the skin", whereas the zone in the middle of the cavity is called "the core". Between them, there is an intermediate zone, sometimes called "the shear zone" due to the fountain flow, as can be seen in Figure 1.

Previous research was first focused on the effects of both the melt and mould temperatures or the holding pressure on the molecular structure; then, on the influence of the injection speed on the skin thickness and mechanical properties. ${ }^{8-10}$ However, only a few papers deal with the microhardness of the skin and the core structure in correlation with the tensile properties.

This paper describes the effects of different processing parameters during injection moulding such as the melt and mould temperatures and the injection speed on the thickness of the skin layer and the mechanical pro- 


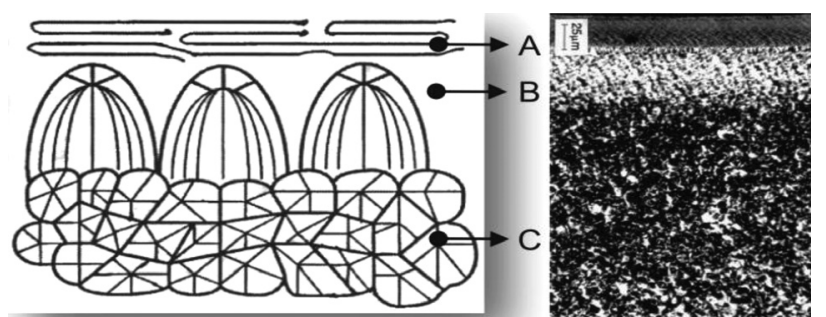

Figure 1: Morphological structure: ${ }^{7} \mathrm{~A}$ - non-spherulitic skin, B intermediate zone, $\mathrm{C}$ - inner spherulitic core

Slika 1: Morfologija strukture: ${ }^{7}$ A - ne-sferulitna skorja, B - vmesno področje, C - notranje sferulitno jedro

perties of the samples with different morphological structures as well as the microhardness of the skin and core.

\section{EXPERIMENTAL WORK}

\subsection{Material and sample preparation}

Throughout this study, the isotactic polypropylene with the commercial name PP HD $601 \mathrm{CF}$, provided by Borealis, was used. This material is characterized by the melt flow index of $8.0 \mathrm{~g} / 10 \mathrm{~min}\left(230{ }^{\circ} \mathrm{C} / 2.16 \mathrm{~kg}\right.$, ISO 1133).

The tensile bars, shown in Figure 2, were injection moulded under different processing conditions (Table 1) from PP pellets using an Arburg Allrounder 370S injection-moulding machine (Germany) with a screw diameter of $20 \mathrm{~mm}$.

Table 1: Processing conditions of injection moulding Tabela 1: Pogoji procesiranja pri vbrizgavanju

\begin{tabular}{|c|c|c|}
\hline Parameters & Value & Units \\
\hline Melt temperature & 190,220 & ${ }^{\circ} \mathrm{C}$ \\
\hline Mould temperature & 20,90 & ${ }^{\circ} \mathrm{C}$ \\
\hline Injection speed & $10,60,150$ & $\mathrm{~mm} / \mathrm{s}$ \\
\hline Injection pressure & 55 & $\mathrm{MPa}$ \\
\hline Holding pressure & 45 & $\mathrm{MPa}$ \\
\hline Holding time & 5 & $\mathrm{~s}$ \\
\hline
\end{tabular}

\subsection{Morphological structure}

The morphological structure of the injection-moulded specimens was characterized with an Olympus polarized light microscope at a $100 \times$ magnification. $30-\mu \mathrm{m}$ micro-

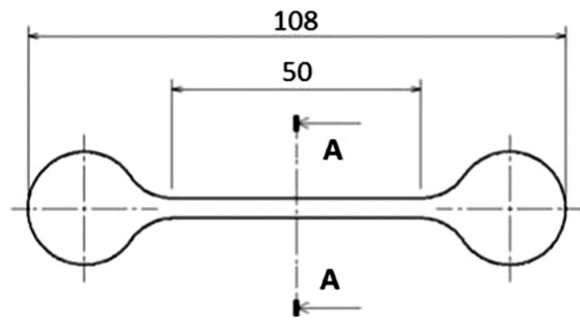

Figure 2: Dimensions of tensile specimens Slika 2: Dimenzije nateznih preizkušancev tome samples were cut with a Leica RM225 rotational microtome in the centre of the tensile bars, perpendicular to the flow direction.

\subsection{Mechanical properties}

The tensile properties of the specimens were determined using a ZWICK 1456 testing machine at $25^{\circ} \mathrm{C}$; the crosshead speed was $50 \mathrm{~mm} / \mathrm{min}$. A total of 10 specimens obtained under two different processing conditions were tested, and the average value was reported.

The microhardness of the core and skin was investigated with a CSM Micro-Combi Tester using a Vickers pyramidal intender according to EN ISO 6507-1. The applied force was $0.5 \mathrm{~N}$ and it was maintained for $90 \mathrm{~s}$; the loading and unloading rate was $1 \mathrm{~N} / \mathrm{min}$. All the samples were measured at $25^{\circ} \mathrm{C}$ and the elastic modulus $\left(E_{\mathrm{IT}}\right)$ was calculated from the unloading curve using the Oliver and Pharr method. ${ }^{11}$ For the measurement of the spherulitic core, tensile samples were cut, with a Buhler IsoMet 4000 cutter, to the thickness of $1 \mathrm{~mm}$. Then, the samples were polished in several steps to ensure smooth surfaces.

\section{RESULTS AND DISCUSSION}

\subsection{Skin-core morphology}

Figures 3 and $\mathbf{4}$ illustrate cross-sectional views of different morphological structures on the surface and in the middle of an injection-moulded tensile sample.

As can be seen, the morphological structure changes through the thickness of the injected samples. On the surface, there is a highly oriented non-spherulitic skin layer, which changes into a micro-spherulitic structure at a certain depth from the surface. This means that in this intermediate transition area a large number of spherulites are nucleated. On the other hand, towards the centre of the sample, the spherulites have a larger size due to a different temperature profile in the cooling stage.

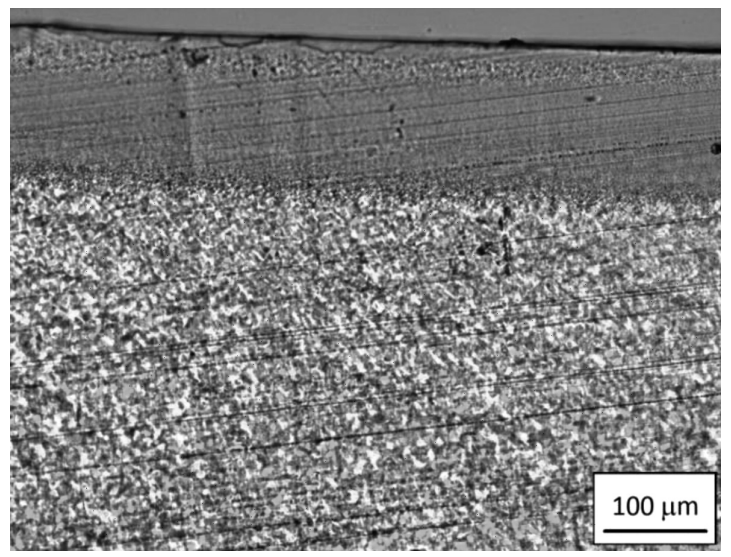

Figure 3: Non-spherulitic surface-layer "skin"

Slika 3: Ne-sferulitna površinska plast "skorja" 


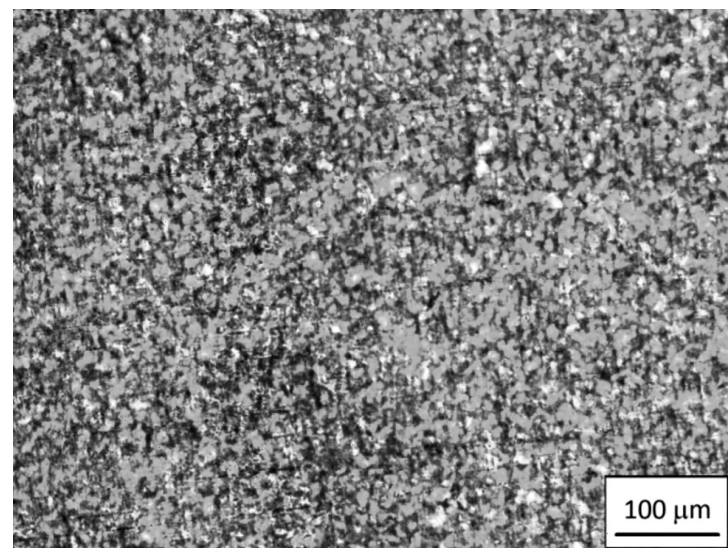

Figure 4: Spherulitic-core structure Slika 4: Struktura sferulitnega jedra

Figure 5 shows the thickness of skin layers depending on the process parameters.

As can be seen, the thickness of the surface layers varies from $124 \mu \mathrm{m}$ to $416 \mu \mathrm{m}$ and is mostly influenced by the injection speed. With a lower speed, the thickness of the skin is higher because the melt front of the material has more time for relaxation and has a greater tendency to be cooled down. With lower mould or melt temperatures, the skin layer also becomes larger. In the case of the highest injection speed, when the mould is filled within $1 \mathrm{~s}$, both the mould and melt temperatures have a negligible effect on the skin thickness.

In comparison with the tensile-bar thickness $(2 \mathrm{~mm})$, the largest skin layer, at both sides, occupies more than $40 \%$ of the total sample thickness and this percentage can have an important influence on the mechanical properties, while the thickness of the skin layer of a thicker injection-moulded component has a minor effect.

The spherulite size in the core and the quantity of the intermediate phase, affected by the shear stress, also influence the total tensile strength and must be taken into consideration.

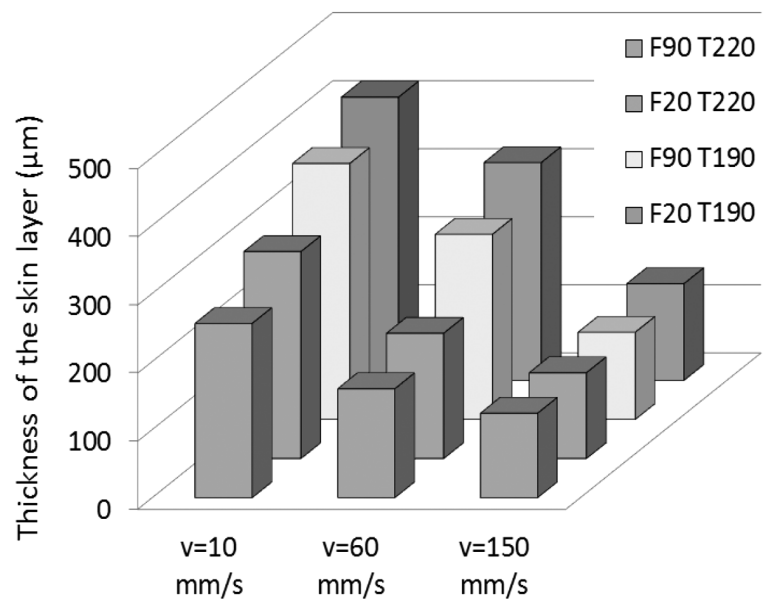

$* F$ - mould temperature, $T$ - melt temperature, $v$ - injection speed Figure 5: Thickness of both skin layers of the samples Slika 5: Debelina obeh površinskih plasti na vzorcih

\subsection{Tensile properties}

A tensile measurement was performed for two series of the samples injected under different processing conditions; sample A with a larger skin, where the thickness of both skin layers was approximately around $0.83 \mathrm{~mm}$ in the cross-section perpendicular to the flow direction and sample B with the total thickness of both skins of around $0.25 \mathrm{~mm}$.

The process parameters for each series of the samples were as follows:
A: $F=20$
${ }^{\circ} \mathrm{C}, T=190{ }^{\circ} \mathrm{C}, v=10 \mathrm{~mm} / \mathrm{s}$
B: $F=90{ }^{\circ} \mathrm{C}, T=220{ }^{\circ} \mathrm{C}, v=150 \mathrm{~mm} / \mathrm{s}$

where $F$ is the mould temperature, $T$ is the melt temperature and $v$ is the injection speed.

Figure 6 illustrates the difference in tensile-stress progress for samples A and B. The obtained results are listed in Table 2, where $E$ is the Young's modulus, $\sigma_{\max }$ is the maximum nominal stress and $\varepsilon_{\sigma \max }$ is the strain at $\sigma_{\max }$.

Table 2: Tensile properties

Tabela 2: Natezne lastnosti

\begin{tabular}{|c|c|c|c|c|c|c|}
\hline Sample & $E / \mathrm{MPa}$ & $s d / \mathrm{MPa}$ & $\sigma_{\max } / \mathrm{MPa}$ & $s d / \mathrm{MPa}$ & $\varepsilon_{\sigma \max } / \%$ & $s d / \%$ \\
\hline $\mathrm{A}$ & 1787 & 85.90 & 35.55 & 0.32 & 7.79 & 0.31 \\
\hline $\mathrm{B}$ & 1476 & 22.21 & 34.67 & 0.38 & 9.52 & 0.19 \\
\hline
\end{tabular}

As can be seen, sample A with the larger skin layers demonstrated the higher tensile strength and Young's modulus, while the elongation at $\sigma_{\max }$ was a bit smaller than for sample B. This means, that highly oriented molecules of the surface layer have better mechanical properties in the flow direction, except for ductility.

The results indicate that the processing condition during injection moulding play an important role, particularly for the thin-walled products, where the thickness of the skin layer influences the final mechanical properties of the injected components.
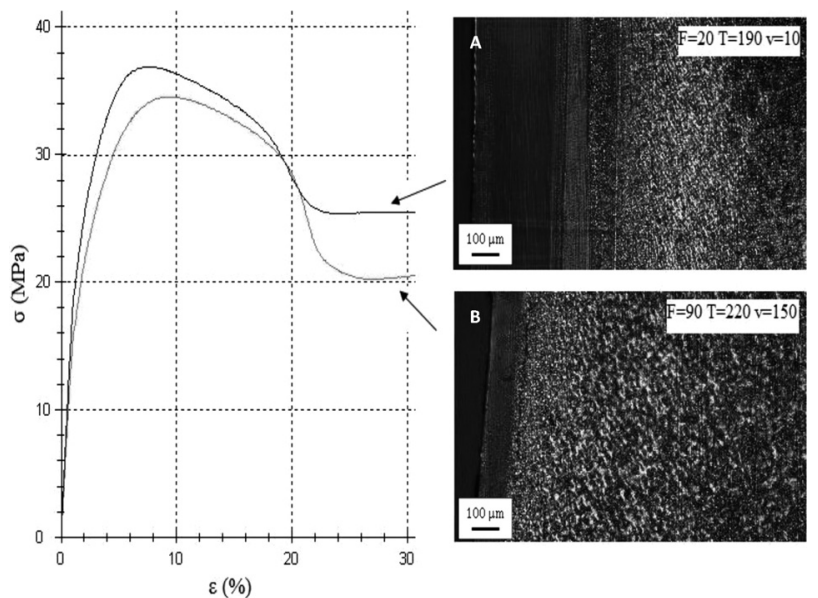

Figure 6: Stress versus strain curves of samples A and B

Slika 6: Krivulji napetost-raztezek vzorcev A in B 


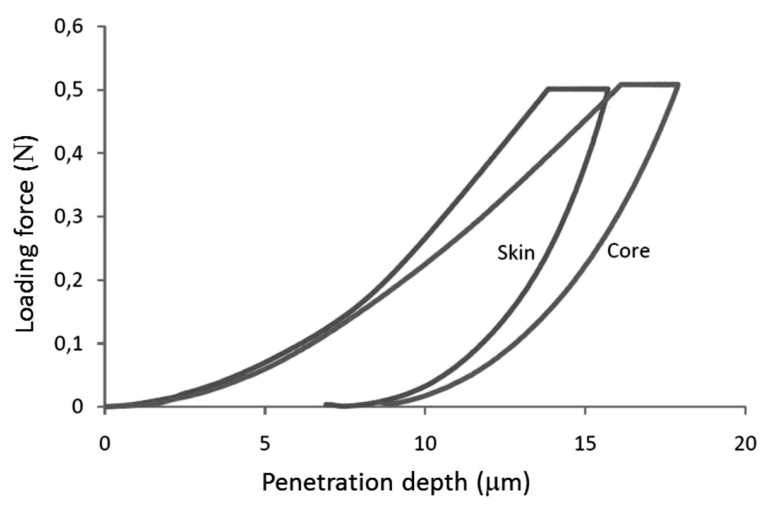

Figure 7: Indentation force versus indentation depth Slika 7: Sila vtiskovanja v odvisnosti od globine vtiskovanja

\subsection{Microhardness properties}

A microhardness test for the skin and core was carried out on sample A and Figure 7 demonstrates the correlation between the force and the penetration depth. The obtained results for the microhardness are shown in Table 3, where $H_{\mathrm{IT}}$ is the indentation hardness, $E_{\mathrm{IT}}$ is the indentation modulus and $C_{\mathrm{IT}}$ is the indentation creep.

Table 3: Microhardness values

Tabela 3: Vrednosti mikrotrdote

\begin{tabular}{|c|c|c|c|c|c|c|}
\hline Sample & $H_{\mathrm{IT}} / \mathrm{MPa}$ & $s d / \mathrm{MPa}$ & $E_{\mathrm{IT}} / \mathrm{GPa}$ & $s d / \mathrm{GPa}$ & $C_{\mathrm{IT}} / \%$ & $s d / \%$ \\
\hline Skin & 107.47 & 3.97 & 2.1527 & 0.47 & 13.36 & 0.275 \\
\hline Core & 92.911 & 3.52 & 1.3083 & 0.51 & 10.31 & 0.314 \\
\hline
\end{tabular}

As can be seen, the measured values in Table $\mathbf{3}$ as well as the penetration depth showed a difference in the microhardness of the highly oriented skin layer and the spherulitic core.

The indentation hardness $\left(H_{\mathrm{IT}}\right)$ of the skin is higher than that of the core by about $14 \mathrm{MPa}$, the indentation modulus $\left(E_{\mathrm{IT}}\right)$ is higher by about $0.8 \mathrm{GPa}$ and the creep $\left(C_{\mathrm{IT}}\right)$ is at approximately the same level. The same trend was confirmed with the tensile test, where a higher strength was demonstrated for the samples with larger skin layers.

\section{CONCLUSION}

In this study, it was confirmed that the injectionmoulding process parameters influence the internal morphological skin-core structure of isotactic PP. In particular, due to a decrease in the injection velocity, the thickness of the surface-skin layer became larger.

Another significant effect was also exhibited by the mould and melt temperatures; but at a high injection rate, when the mould cavity was filled within $1 \mathrm{~s}$, the influence of these parameters was not significant and the thickness of the skin layers remained substantially constant.
Mechanical testing showed that the samples with a larger skin-core effect had a higher tensile strength and Young's modulus, while the ductility of the samples was decreasing. The same results were obtained from the microhardness, where the skin structure was harder than the spherulites in the centre of the sample.

This influence on the mechanical properties is important especially for the thin-walled products. On the other hand, in the case of thicker samples, the skin-core effect has a negligible influence.

\section{Acknowledgments}

This work was supported by the Ministry of Education, Youth, and Sports of the Czech Republic - Program NPU I (LO1504). This study was also supported by the internal grant of TBU in Zlin IGA/FT/2016/002 funded from the resources of the specific university research. The authors would like also to thank Petra Pavelova for her help with mechanical testing.

\section{REFERENCES}

${ }^{1}$ A. E. Woodward, Understanding polymer morphology, Hansen/ Gardner Publication, Ohio, USA 1995

${ }^{2}$ J. C. Viana, Development of the skin layer in injection moulding: phenomenological model, Polymer, 45 (2004) 3, 993-1005, doi:10.1016/j.polymer.2003.12.001

${ }^{3}$ M. R. Kantz, H. D. Newman, F. H. Stigale, The skin-core morphology and structure-property relationships in injection-moulded polypropylene, J. Appl. Polym. Sci., 16 (1972), 1249-1260, doi:10.1002/app.1972.070160516

${ }^{4}$ G. Kumaraswamy et al., Shear-enhanced crystallization in isotactic polypropylene: Part 2, Analysis of the formation of the oriented "skin", Polymer, 41 (2000) 25, 8931-8940, doi:10.1016/S00323861(00)00236-6

${ }^{5}$ J. W. Housmans, M. Gahleitner, G. W. Peters, H. E. Meijer, Structure-property relations in molded, nucleated isotactic PP, Polymer, 50 (2009) 10, 2304-2319, doi:10.1016/j.polymer.2009.02.050

${ }^{6}$ T. Jaruga, E. Bociagga, Structure of polypropylene parts from multicavity injection mould, Archives of Materials Science and Engineering, 28 (2007) 7, 429-432

${ }^{7}$ F. Lednický, Microscopy and morphology of polymers, $1^{\text {st }}$ ed., Technical university of Liberec, CZ 2009

${ }^{8}$ M. Obadal, R. Čermák, N. Baran, K. Stoklasa, J. Šimoník, Impact strength of $\beta$-nucleated polypropylene, International Polymer Processing, 19 (2004) 1, 35-39, doi:10.3139/217.1802

${ }^{9}$ M. Fujiyama, Structures and Properties of Injection Mouldings of $\beta$-Crystal Nucleator-Added Polypropylenes: Part 1 , Effect of $\beta$-Crystal Nucleator Content, Int. Polym. Proces., 10 (1995) 2, 172-178, doi: $10.3139 / 217.950172$

${ }^{10}$ R. Čermák, M. Obadal, P. Ponížil, M. Polášková, K. Stoklasa, A. Lengálová, Injection-moulded $\alpha$ - and $\beta$-polypropylenes: I. Structure vs. processing parameters, Eur. Polym. J., 41 (2005) 8, 1838-1845, doi:10.1016/j.eurpolymj.2005.02.020

${ }^{11}$ W. C. Oliver, G. M. Pharr, An improved technique for determining hardness and elastic modulus using load and displacement sensing indentation experiments, J. Mater. Res., 7 (1992) 6, 1564-1583, doi:10.1557/JMR.1992.1564 